Int. Archs Allergy appl. Immun. 1976;52:I-V

\title{
Contents, Vol. 52, 1976
}

\section{To Our Readers 1}

Corner, L. A.; Outteridge, P. M.; Pearson, C. W., and Lepper, A. W. D.: Immune Mechanisms Affecting Bovine Leucocytes during Suppression of Tuberculin Skin Sensitivity in Cattle. 3

Molls, M. and Bernauer, W.: Effect of Catecholamines and Sympatholytics on Survival and Circulatory Parameters in Protracted Anaphylactic Shock of Guinea Pigs 15 Smith, S. R. and Petillo, J.: IgE Production in Five Inbred Rat Strains Following Immunization with Alum-Precipitated Egg Albumin . 21

Roy, R.; McNicoll, J., and Daguillard, F.: Immunological Activities of Rat Lymphocytes. I. Mitogenic Responses and Surface Markers of Lymphocytes from Normal, Thymectomized and B Rats 32

Quismorio, F. P.; Friou, G. J.; Schneider, J.; Hutchinson, M., and Harding, B.: In vitro Activity of Anti-DNA Antibodies from SLE Patients in Antibody-Dependent Cell-Med iated Cy totoxicity 42 Zweiman, B.; Slott, R. I., and Atkins, P. C: Factors in the Tissue Eosinophil Responses in Human Immediate Hypersensitivity Reac tions 48

Miller, P. and Church, M. K.: Sequential Release of Histamine and 5-Hydroxytryptamine dur ing Pinnal Anaphylaxis in the Mouse 53

Elsayed, S.; Apold, J.; Aas, K., and Bennich, H.: The Allergenic Structure of Allergen M from Cod. I. Tryptic Peptides of Fragment TM 159

Mitchell, G. F.; Hogarth-Scott, R. S.; Edwards, R. D.; Lewers, H. M.; Cousins, G., and Moore, T.: Studies on Immune Responses to

Parasite Antigens in Mice. I. Ascaris suum Larvae Numbers and Antiphosphorylcholine Responses in Infected Mice of Various Strains and in Hypothymic nu/nu Mice 64 Mitchell, G. F.: Studies on Immune Responses to Parasite Antigens in Mice. II. Aspects of the T cell Dependence of Circulating Reagin Production to Ascaris suum Antigens 79 
Mitchell, G. F.; Hogarth-Scott, R. S.; Edwards, R. D., and Moore, T.: Studies on Immune Responses to Parasite Antigens in Mice. III. Nippostrongylus brasiliensis Infections in Hypothymic nu/nu Mice 95 Touraine, J. L.; Touraine, F.; Hadden, J. W.; Hadden, E. M., and Good, R. A.: 5-Bromodeoxyuridine-Light Inactivation of Human Lymphocytes Stimulated by Mitogens and Allogeneic Cells: Evidence for Distinct TLymphocyte Subsets 105 Stewart-Tull, D. E. S.; Shimono, T.; Kotani, S., and Knights, B. A.: Immunosuppressive Effect in Mycobacterial Adjuvant Emulsions of Mineral Oils Containing Low Molecular Weight Hydrocarbons 118

Palosuo, T.; Andres, G. A., and Milgrom, F.: A Ubiquitous Tissue Antigen and its Cor responding Antibody in Sera of Patients with Glomerulonephritides 129

Andres, G. A.; Kano, K.; Elwood, C.; Prezyna, A.; Sepulveda, M., and Milgrom, F.: Im mune Deposit Nephritis in Infectious Mononucleosis 136

Hedin, H.; Richter, W., and Ring, J.: DextranInduced Anaphylactoid Reactions in Man. Role of Dextran Reactive Antibodies 145

IV

Contents

Jacobson, R. H. and Reed, N. D.: The Requirement of Thymus Competence for Both Humoral and Cell-Mediated Steps in Expulsion of Nippostrongylus brasiliensis from Mice .. 160 Griswold, W. R.; Stafford, A., and Incaudo, G. A.: Cryoprecipitates and Immune Com plexes : Differentiation between Cold Insolu ble Immune Complexes and Nonspecific Cryoprecipitates 169 Tomar, R. H. and Knight, R.: Cellular Require ments for Simulation by the Purified Streptococcal Antigen DSR 175

Rose, J. E. M. St.; Murray, G. W., and Howe, S. A.: Effect of Alterations in Metabolic Rate on the Duration of Tolerance in Neonatally Injected Animals 183

Gery, I.; Schiffman, Z.; Weiss, I., and Mugraby, L.: Effects of in vivo Administered B. per 
tussis and Other Adjuvants on the Mitotic

Responses of Lymphocytes in vitro 188

Baxter, J. H. and Adamik, R.: Studies on Pas

sive Transfer of Anti-Dextran and Anti-Egg

Albumin Reactivity in the Rat 196

Seegal, B. C.; Hsu, K. C.; Lattimer, J. K.; Habif,

D. V., and Tannenbaum, M.: Immuno-

globulins, Complement and Foreign Anti

gens in Human Tumor Cells 206

Luster, M. I.; Leslie, G. A., and Bardana, E. J.: Structure and Biological Functions of Human

IgD. VII. IgD Antinuclear Antibodies in Sera of Patients with Autoimmune Disorders 212

Wide, L.: A RAST Neutralization Test for De

tection of Blocking Antibodies in Serum after

Hyposensitization 219

Ring, J.; Seifert, J.; Seiler, F., and Brendel, W.: Improved Compatibility of ALG Therapy by

Application of Aggregate Free Globulin. 227

Mitchell, G. F. and Lewers, H. M.: Studies on

Immune Responses to Parasite Antigens in

Mice. IV. Inhibition of an Anti-DNP Anti

body Response with the Antigen, DNP-Ficoll

Containing Phosphorylcholine 235

Asherson, G. L.; Zembala, M., and Wood, P. J.:

Occurrence of Suppressor Cells in Lymph

Nodes and Spleen at Later Times after Im

munization with the Contact-Sensitizing

Agent Picryl Chloride 241

Kraft, D.; Wilson, D. V., and Devey, M. E.: Penicillin Allergy Studies by a Modified Red-Cell-

Linked Antigen-Antiglobulin Reaction 248

Moav, N.; Steinberg, L., and Frensdorff, A.:

Effect of Vinblastine on the Early Events in

the Humoral Immune Response of Mice to

SRBC 257

Muscoplat, C. C; Setcavage, T. M.; Thoen,

C. O., and Kim, Y. B.: Enhancement of

Humoral Immune Responses. I. Potentiating

Influence of Purified Protein Derivative on

the in vitro Immune Response of Spleen Cells

Sensitized to Mycobacterium bovis and Myco-

bacterium avium 266

Gupta, S.; Goel, Z., and Grieco, M. H.: Fetuin. In vitro Effect on Sheep Erythrocyte Rosette

Formation with Human T Lymphocytes ... 273

Eremin, O.; Plumb, D., and Coombs, R. R. A.: T and B Lymphocyte Populations in Human

Normal Lymph Node, Regional Tumour Lymph Node and Inflammatory Lymph Node 277

Rothschild, H.; Wilson, M.; Lopez, M.; Salvag-

gio, J., and Bice, D.: An Immunological In 
vestigation of a Family with Chronic Muco-

cutaneous Candidiasis 291

Riddel, M.; Baker, R.; Lind, A.; Norlin, M.; and Ouchterlony, Ö.: Studies on the Intergenerical Precipitinogen $\beta$ with Special Re ference to its Presence in Mycobacterial Ribosomes 297

Richter, A. W. and Belder, A. N. de: Antibodies against Hydroxyethylstarch Produced in Rabbits by Immunization with a ProteinHydroxyethylstarch Conjugate $\quad 307$ Ts'ao, C.; Metzger, W. J.; Patterson, R., and Suszko, I. M.: Histamine-Containing Cells in Bronchial Lavage Fluid. I. Ultrastructural Characterization and Comparison with Mast Cells in Three Types of Tissues of Rhesus Monkeys 315 Jokipii, A. M. M.; Jokipii, L., and Kosunen, T. U.: Organ Distribution of Immunocompetent Cells in Guinea Pigs. II. Spleen, Lymph Node, Bone Marrow, or Thymus Cells in the Restoration of the Splenic Plaque-Forming Cell Response to Sheep Erythrocytes after Irradiation 325 Puri, S. K.; Mathé, A. A., and Volicer, L.: Adenylate Cyclase Activity in Heart and Lung: Effect of Epinephrine and Histamine in Control and Sensitized Guinea Pigs 331

Eriksson, N. E.; Ahlstedt, S., and Belin, L.: Diagnosis of Reaginic Allergy with House Contents $\mathrm{V}$

Dust, Animal Dander and Pollen Allergens in Adult Patients. I. A Comparison Between RAST, Skin Tests and Provocation Tests .. 335

Kraft, D.; Franks, D., and Coombs, R. R. A.:

Characterization of K-Cell Activity by Use of Depletion Experiments 347

Socha, W. W.; Wiener, A. S.; Moor-Jankowski, J., and Valerio, D.: The First Isoimmune Blood Group System of Rhesus Monkeys (Macaca mulatta): the Graded Drh System . 355 Johansson, S. G. O. and Deuschl, H.: Immuno-globulins in Nasal Secretion with Special Reference to IgE. I. Methodological studies 364

Deuschl, H.: Immunoglobulins in Nasal Secretion with Special Reference to IgE. II. Seasonal Studies of Timothy-Specific IgE-Anti-body in Patients with Allergic Rhinitis .... 376

Johansson, S. G. O.; Kjessler, B., and Sherman, M. S.: Determination of $\alpha$-Fetoprotein by a 
New Paper Disc Radioimmunoassay of the

Sandwich Type

384

Blands, J.; Diamant, B.; Kallós, P.; Kallós-

Deffner, L., and Løwenstein, H.: Flour

Allergy in Bakers. I. Identification of Allergenic Fractions in Flour and Comparison of

Diagnostic Methods 392

Short Communications

Harper, D. and West, G. B.: Anaphylactoid

Reactions in Rats and the Blood Sugar Level 407

Middelkoop, O. P.; Veldhuizen, R. W., and Scheper, R. J.: E and EAC Rosette-Forming Cells in Healthy Donors and Cancer Patients 412

Ruscetti, S. K.; Gill, T. J.; Salvin, S. B.; Herrmann, J., and Bailie, C. W.: Production of

Migration Inhibitory Factor in Inbred Rats. 417

Matre, R. and Grov, A.: Inhibition of Ana-

phylactic Reaction in Guinea Pigs by Anti

bodies to Fragments of Fc form Autologous

$\mathrm{IgG} \quad 422$

Anderson, R. E.; Warne, P. J., and West, G. B.:

Carrageenan and Dextran in Rats 425

Letter to the Editor

Hirschfeld, J.: Serologic Languages and the At-

A2 Blood Groups $\quad 428$

Author Index 432 